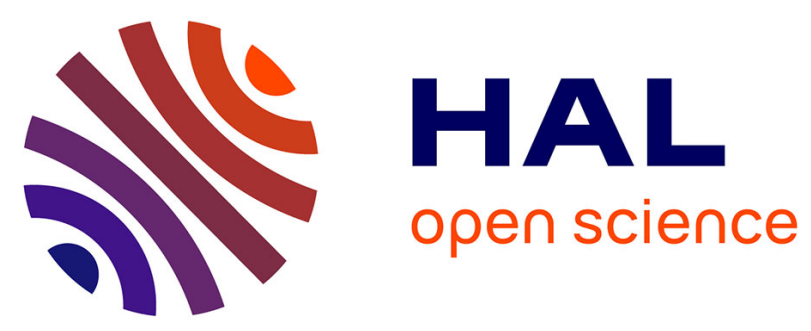

\title{
Onsite advanced biocleaning system for historical wall paintings using new agar-gauze bacteria gel
}

\author{
G. Ranalli, E. Zanardini, Laura Rampazzi, C. Corti, A. Andreotti, M.P.
}

Colombini, P. Bosch-roig, G. Lustrato, C. Giantomassi, D. Zari, et al.

\section{- To cite this version:}

G. Ranalli, E. Zanardini, Laura Rampazzi, C. Corti, A. Andreotti, et al.. Onsite advanced biocleaning system for historical wall paintings using new agar-gauze bacteria gel. Journal of Applied Microbiology, 2019, 126 (6), pp.1785-1796. 10.1111/jam.14275 . hal-03149130

\author{
HAL Id: hal-03149130 \\ https://hal.science/hal-03149130
}

Submitted on 22 Feb 2021

HAL is a multi-disciplinary open access archive for the deposit and dissemination of scientific research documents, whether they are published or not. The documents may come from teaching and research institutions in France or abroad, or from public or private research centers.
L'archive ouverte pluridisciplinaire $\mathbf{H A L}$, est destinée au dépôt et à la diffusion de documents scientifiques de niveau recherche, publiés ou non, émanant des établissements d'enseignement et de recherche français ou étrangers, des laboratoires publics ou privés. 


\title{
Onsite advanced biocleaning system on ancient wall paintings using new agar-gauze bacteria gel
}

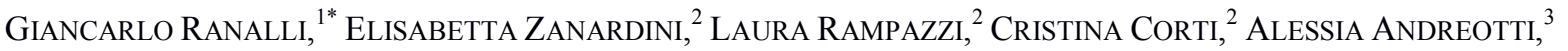 \\ Maria Perla Colombini, ${ }^{3}$ Pilar Bosch-Roig, ${ }^{4}$ Giuseppe Lustrato, ${ }^{1}$ CARlo Giantomassi, ${ }^{5}$ Donatella Zari, ${ }^{5}$ \\ PAOLO VIRILLI ${ }^{6}$
}

\author{
${ }^{1}$ Department of Bioscience and Territory, University of Molise, Pesche, Italy \\ ${ }^{2}$ Department of Science and High Technology, University of Insubria, Como, Italy \\ ${ }^{3}$ Department of Chemistry and Industrial Chemistry, University of Pisa, Pisa, Italy \\ ${ }^{4}$ Department of Conservation and Restoration of Cultural Heritage, Universitat Politècnica de València, \\ Valencia, Spain \\ ${ }^{5}$ Direzione Tecnica dell'Opera della Primaziale Pisana, Pisa, Italy \\ ${ }^{6}$ Tecnireco srl, Spoleto, Italy.
}

*Corresponding author. Mailing address: Department of Bioscience and Territory, University of Molise, c. da Fonte Lappone, 86090 Pesche, Italy. Phone: 39-0874404155. Fax: 39-0874404123. E-mail: ranalli@unimol.it.

\begin{abstract}
Aims: In this study the results of the use of a new agar-gauze biogel system activated by viable bacterial cells applied on altered wall-paintings are reported.

Methods and Results: Biocleaning using agar biogel and agar-gauze biogel systems was performed onsite by direct application onto altered wall-painting artwork surfaces $\left(25-1,000 \mathrm{~cm}^{2}\right)$. The treatments were performed for the restoration of two original Italian sites: i) at the Vatican Museums, Cristo che salva Pietro dalle acque - La Navicella wall-painting by Giovanni Lanfranco (1627-1628) and ii) at Pisa Cathedral Cupola, Incarnato wallpainting by Orazio Riminaldi (1593-1630) and his brother (Girolamo Riminaldi). The novelty of this study is the use of Pseudomonas stutzeri A29 viable cells using an advanced agar-gauze biogel system and that the bioapplications required short contact-times of between 3-12 hours. The ancient artworks were altered by lipid and protein residues from past restoration as confirmed by the Py-GC/MS and FTIR data. Assessment was made on the effectiveness of the biological treatment and general considerations were discussed.

Conclusions: The short contact-time of the bioapplications using advanced agar-gauze gel activated with P. stutzeri viable cells makes this biotechnology promising as an alternative method to the traditional onsite cleaning techniques currently in use for altered ancient wall-paintings.

Significance and Impact of the Study. In this study, we report the biocleaning of altered materials located in vertical and vaulted areas using agar-gauze biogel and short application times for the first time. These findings are of great significance for future restoration activities, being crucial for determining best preservation strategies in this field.
\end{abstract}

Keywords: Onsite biocleaning, biorestoration, wall-paintings, agar-gauze biogel, bacteria. 


\section{Introduction}

Up to date biocleaning processes have been successfully applied on real-scale lithoid artwork, such as stoneworks and buildings (Antonioli et al. 2005; De Belie et al. 2005; De Graef et al. 2005; Ranalli et al. 2005; Cappitelli et al. 2006, Cappitelli et al, 2007; May et al. 2008; Polo et al. 2010; Alfano et al. 2011; Gioventù et al. 2011; Barbabietola et al. 2012; Lustrato et al. 2012; Bosch-Roig et al. 2013a, Bosch-Roig et al. 2013b; Troiano et al. 2013; Mazzoni et al. 2014; Barras 2018). In all these studies, the most common alterations were black crusts, nitration, sulphation, salt efflorescence and the deposition of dust and organic compounds as hydrocarbons as a consequence of atmospheric pollution (Gauri et al. 1989; Saiz-Jimenez 1995; Saiz-Jimenez 2004; Doehne and Price 2010). Recently, a characterization of biodegradation processes occurring in a 17th century easel painting and the potential decontaminating activity of a biocompound has been investigated to prevent biodeterioration of artworks (Caselli et al. 2018). Other successful biorestoration treatments have been recently carried out on frescoes at the Camposanto Monumentale in Pisa; in this case the specific aim was to remove the gauze, glued to the paint surface, which was used in the "strappo" technique during the World War II to detach frescoes from the original walls after a bomb (Ranalli et al. 2003a; Antonioli et al. 2005; Ranalli et al. 2005; Ranalli et al. 2018).

On the contrary, little has been done on wall-paintings; one of the main complications, frequently encountered, is the presence of organic compounds which have been applied and not completely removed during previous and/or inappropriate restoration interventions. These organic residues can be altered and weathered over time and can represent a danger to the conservation of artwork. Such residual compounds, under favourable environmental conditions, can, in fact, be an adequate growth substrate both for bacteria and fungi, which can alter and deteriorate surfaces, causing chemical, mechanical and aesthetic damage to the materials. Therefore, the removal of these organic residues is crucial and, together with the traditional cleaning methods, the use of enzymes has been also considered in some cases (Cremonesi, 1999; Wolbers, 2000).

In order to apply a biocleaning technology to a different type of artistic materials such as wall paintings, the procedure requires specific analytical investigations to identify and distinguish organic compounds originally present in the paintings from those deriving from restoration interventions.

The materials undergo transformation through natural ageing processes and these effects are no less important. Cultural Heritage artworks are obviously unique, so they are usually characterized by low homogeneity and the various compounds to be identified are generally present in low concentrations. Therefore, the use of sensitive, selective and, if possible, non-destructive techniques is crucial and, strongly recommended, such as the use of FTIR and gas chromatography-mass spectrometry (GC/MS) (Colombini et al. 1999, Colombini et al. 2003; Andreotti et al. 2009; Rampazzi et al. 2016). Thus, once the unwanted organic matter has been identified on wall paintings and the difficulty in removing them by traditional methods has been verified, the use of biological systems may represent a valid, suitable alternative method to use.

In this paper, we illustrate the application of a biocleaning technology on wall-paintings using agar-gauze, biogelactivated bacteria as an advanced delivery system. The agar-gauze gel, enriched with viable bacterial cells as "biorestoration" agents, was used in two different sites: the wall painting Cristo che salva Pietro dalle acque - La Navicella at the Vatican Museums and the wall painting Incarnato in the Cupola inside Pisa Cathedral.

Our main task was to perform advanced, fast, onsite biocleaning using agar-gauze biogel activated with $P$. stutzeri viable cells on the two artworks cited above in order to degrade the organic substances present as residues from past restoration and which were affecting the substratum layers on the ancient wall-paintings. The following steps were taken: 
i) Chemical-characterisation analytical techniques were used to identify the original organic compounds, the substances produced by their degradation, organic matter used in previous restorations and compounds produced by inorganic decay, as well as their effectiveness and effects over time by Py-GC/MS and FTIR;

ii) Onsite fast bioapplication to remove the undesirable matter present on ancient wall-paintings by advanced agargauze gel activated with $P$. stutzeri viable cells.

\section{Materials and methods}

\section{Description of the selected wall paintings}

Two ancient wall paintings were selected for the onsite biocleaning studies: Cristo che salva Pietro dalle acque (also known as La Navicella) at the Vatican Museums in Rome, and the Incarnato in the Cupola at Pisa Cathedral (Table 1).

Cristo che salva Pietro dalle acque - La Navicella - The painting chosen from those present at the Vatican Museums in Rome was an oil-painting fresco called La Tempesta Sedata or Cristo che salva Pietro dalle acque - La Navicella. It was painted by the Italian artist Giovanni Lanfranco between 1627 and 1628 using a mixed technique (Figure 1a). Originally this wall-painting was in the Saint Peter Basilica in Rome, but it was detached from the wall in 1721 and transferred to the present location in the Aula delle Benedizioni at the Vatican Museums, where the onsite biocleaning application was carried out. Initially, this wall-painting was irregularly covered by residual substances which altered the paint surface and that were visible even to the naked eye in some areas.

Cupola wall paintings - Incarnato. Among the ancient paintings present in the Cupola inside Pisa Cathedral (Figure 1b), the Incarnato wall-painting (about $300 \mathrm{~m}^{2}$ ) was painted by Orazio Riminaldi (1593-1630) and his brother (Girolamo Riminaldi). Since the end of the $17^{\text {th }}$ Century, this wall-painting has been a complex example referred to as a "style defined by whirling and radiant circular motion" (turbinoso e radioso movimento circolare) due to the peculiarity of figures painted on the vertical, vaulted and oblique internal walls in the Cupola. This wall-painting showed alterations in terms of undesirable substances covering and altering the original noble paint layer and, therefore, the aim of the biocleaning application was to remove these undesirable residual substances.

Table 1 Works of art selected, samples, type of alterations and methodology.

\begin{tabular}{lll}
\hline Artworks & $\begin{array}{l}\text { Cristo che salva Pietro dalle acque } \\
\text { La Navicella, Vatican Museums, Rome }\end{array}$ & $\begin{array}{l}\text { Incarnato, } \\
\text { Cupola Cathedral, Pisa }\end{array}$ \\
\hline $\begin{array}{l}\text { Site of painting } \\
\text { Surface }\left(\mathrm{m}^{2}\right)\end{array}$ & On vertical wall, at $8 \mathrm{~m}$ from the floor & On vaulted wall, at 50 $\mathrm{m}$ from the ground \\
Site of samples & 11.0 & 350 \\
Substance to remove & Protein residues & 4 (IN1-IN4) \\
Biocleaning systems & Agar biogel, agar-gauze biogel & Protein residues and calcium oxalate \\
& & Agar-gauze biogel \\
Treatment times $(\mathrm{min})$ & 60,150 & 720 \\
\hline
\end{tabular}

\section{Chemical characterization by Py-GC/MS and FTIR}

Small-samples were taken from the surface of both artworks in representative, homogeneous areas with a microscalpel, before and after the bio-treatment (Table 2). A Pyroliser PY3030 by Frontier Laboratories Ltd (Fukushima, Japan) coupled on line with Gas Chromatograph 6890N with Mass Spectrometer detector 5973 (Py-GC/MS by 
Agilent Technologies, Palo Alto, USA) was used for pyrolysis in order to analyse the lipid, proteinaceous fractions of the samples. This analysis was for fundamental identification of the altered substances present on the surfaces of the two artworks studied. A few $\mu \mathrm{g}$ of the sample mixed with $2 \mu 1$ of hexamethyl-disilazane (HMDS) were placed in a quartz tube. Detailed working conditions are published elsewhere (Andreotti et al. 2009, Lluveras et al. 2010; Rampazzi et al., 2012; Orsini et al. 2017).
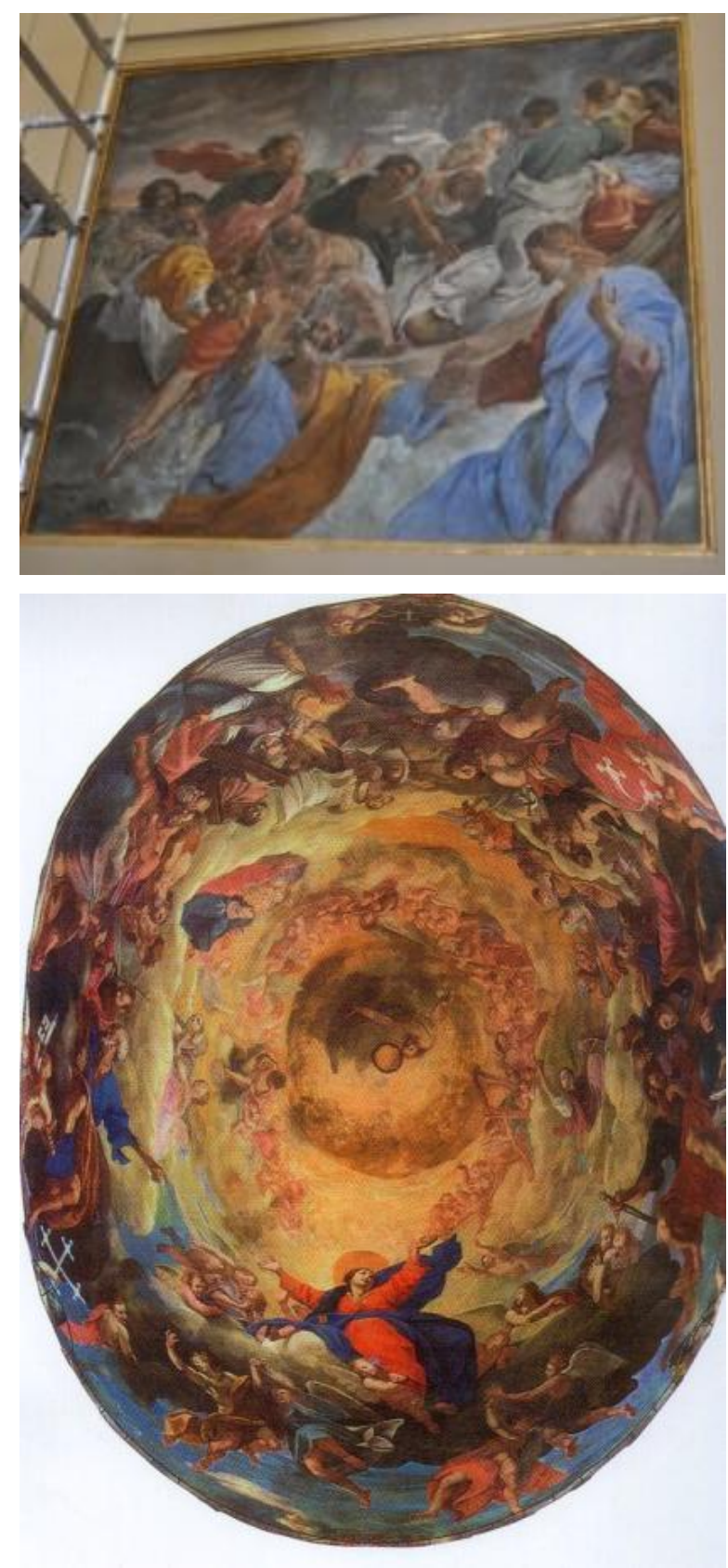

Figures 1a - 1b Images of artworks tested at onsite cleaning. A) La Navicella wall painting, Vatican Museums, Rome. B) Internal wall inside the Cupola at Pisa, Italy.

FTIR and Py-GC/MS analyses were carried out in order to identify the composition of the surface of the samples and to confirm either the increase or the decrease in the compounds present, depending on the intensities of their associated bands or peaks. FTIR spectra were recorded on $\mathrm{KBr}$ pellets (Sigma-Aldrich FTIR Grade) in transmission mode, by a BioRad Excalibur Series FTS 3000 spectrometer (detector DTGS) in the $4000-400 \mathrm{~cm}^{-1}$ range, with a resolution of $4 \mathrm{~cm}^{-1}$. Pellets were prepared by mixing samples and $\mathrm{KBr}$ in an agate mortar, pouring the mixture into 
a press and then applying a pressure of $6 \mathrm{t} / \mathrm{cm}^{2}$ for 1 minute. The powders, from both the surface of microfragments and from the external layers of the polished cross-sections, were sampled under optical microscopy by means of micro-scalpel (Corti et al. 2016). Paper-based database was used to identify the species in each FTIR spectrum, by comparing experimental peaks with reference patterns (Derrick et al., 1999).

\section{Growth conditions of Pseudomans stutzeri A29 strain}

P. stutzeri A29 strain (DIBT Microbial Collection, University of Molise, I) was used for all the bioapplications on the basis of the performances obtained in previous studies (Ranalli et al. 2005; Bosch-Roig et al. 2012; Lustrato et al. 2012). Furthermore, growth conditions of the selected strain and its biodegradation activities were tested before the biocleaning was undertaken (Bosch-Roig and Ranalli, 2018; Ranalli et al. 2018).

The strain was incubated at $28^{\circ} \mathrm{C}$ for $24-36$ hours, on Tryptone Soya broth medium containing pancreatic digest of casein, $17.0 \mathrm{~g} \mathrm{l}^{-1}$ (CM0129, Oxoid Ltd., Basingstoke, England); bacterial growth was monitored by $\mathrm{OD}_{560}$, and cultures were stored on TS Agar medium (Oxoid Ltd., Basingstoke, England).

\section{Bacterial cell and new biogel system for onsite biocleaning}

Suspensions containing exponentially-growing bacteria, of approximately $10^{8} \mathrm{CFU} \mathrm{ml}^{-1}$, were obtained by inoculating $10 \mathrm{ml}$ of an overnight broth-culture into $1,000 \mathrm{ml}$ of fresh broth medium (in a flask with 3,000 $\mathrm{ml}$ total volume) and incubating it in a shaker (200 rpm) for 24 hours at $28^{\circ} \mathrm{C}$. The cells were centrifuged at 7,000 $\mathrm{g}$ for 10 minutes at $4^{\circ} \mathrm{C}$, washed twice with phosphate-buffered saline solution, and re-suspended in sterile distilled water. Final cell concentration was around $10^{8}$ cells $\mathrm{ml}^{-1}$, corresponding to an O.D.560 $\mathrm{nm}$ of about 1.6; $\mathrm{pH}$ was around 7.0 and the solution conductivity was $947.1 \mu \mathrm{sm}^{-1}$. Cells were stored at $4{ }^{\circ} \mathrm{C}$ during transportation from the laboratory to the site for onsite application.

Two types of delivery systems were used to bioclean the selected areas: Agar biogel (Bosch-Roig et al. 2014) for vertical surfaces, as shown in Figure 2a, and advanced agar-gauze biogel for vaulted surfaces, Figure $2 \mathbf{b}$.

Both the biogels were carefully brushed with the suspension cells (P. stutzeri A29 bacteria cells at a concentration of 2-5 $\times 10^{6}$ viable cells $/ \mathrm{cm}^{2}$ ) to favour cell contact and adhesion. For the preparation of the agar-gauze biogel, under sterile cabinet conditions, a thin, sterile, cotton gauze was added at the bottom of sterile plastic vessels covered by hot agar broth (at more than $80^{\circ} \mathrm{C}$ ), obtaining sheets of standard dimensions $\left(25 \times 40 \mathrm{~cm}^{-1}\right.$ and $\left.1,000 \mathrm{~cm}^{2}\right)$ of advanced agar-gauze biogel. After agar solidification (below $45^{\circ} \mathrm{C}$ ), the larger agar-gauze gels were protected by a double layer of plastic PET film (Domopak, Volpiano, Italy), and stored at $4{ }^{\circ} \mathrm{C}$. When required, the plastic cover was removed and the agar-gauze biogels were applied onto the surface of the artworks. If required, the large agargauze biogels were cut using a sterile lancet or scissors in order to obtain sheets of specific dimensions according to the areas to be treated. (Figures S1a-b). 

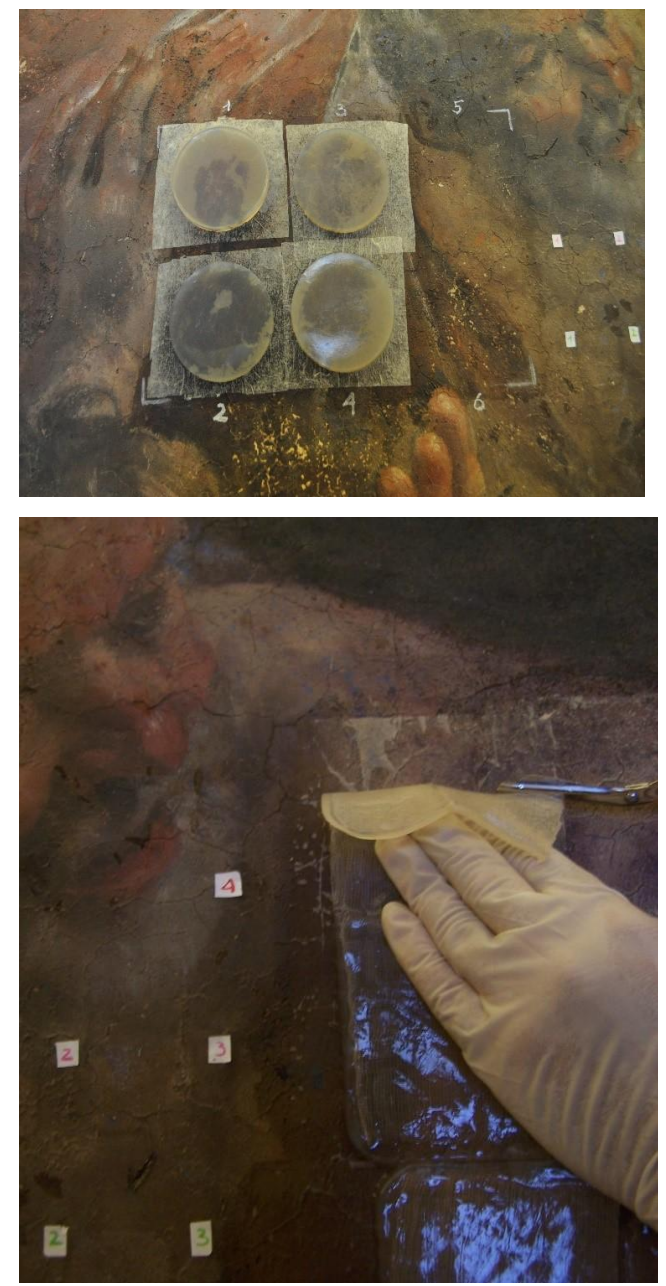

Figures $2 \mathrm{a}-2 \mathrm{~b}$ Images of artwork tested at onsite cleaning, La Navicella wall painting, Vatican Museums, Rome. Detail of biocleaning by traditional agar biogel disks (2a) and advanced agar-gauze biogel activated with $P$. stutzeri (2b).

The bioapplications on wall-paintings were performed on small, representative areas of the entire altered wallpainting surfaces. Representative areas of from around $60 \mathrm{~cm}^{2}$ to around $4,000 \mathrm{~cm}^{2}$ were selected and the biocleaning-treatment contact times varied between 10 and 150 minutes for the Navicella (Figures 3a-3b) and were up to 12 hours for the Cupola wall-paintings (Figures S2a-d). The tests were performed as follows: i) Natural, white, unbuffered, $9.0 \mathrm{~g} / \mathrm{m}^{2}$ Japanese paper (Klug Conservation, Walter GmbH \& Co. KG., Immenstatd, Germany) was applied onto the vaulted and vertical wall-painting surfaces; ii) P. stutzeri A29 viable cell-suspension was used as a biocleaning agent at the bacterial concentration of $2-5 \times 10^{6}$ viable cells $/ \mathrm{cm}^{2}$ as reported above; iii) New agargauze biogel, activated by viable bacterial cells, as an advanced delivery system to favour biocleaning; iv) Agar-gel or agar-gauze gel with sterile water instead of viable bacterial cells were used as negative control.

\section{Monitoring of the effectiveness of the biorestoration process}

One very important aspect of biorestoration is the monitoring of the effectiveness of the process. On the basis of previous studies performed by the same research group, at the end of the biocleaning, treated and control areas were washed with sterile distilled water ( 3 soft manual applications by sponge) and dried at room temperature (Ranalli et al. 2003b; Ranalli et al. 2005, Ranalli et al. 2009).

After the final washing and drying steps, to check the possible presence of residual bacterial cells, sterile swabs (Fissan, Milano, Italy) were used to ensure that no treatment residues were left on the artworks and microbiological 
analyses by plate counting and ATP content determination were performed. Three replicates were always considered for both the biocleaning and the control tests. Temperature was also monitored at both sites by portable data loggers (176 T3 model, Testo SpA, Settimo Milanese, I).
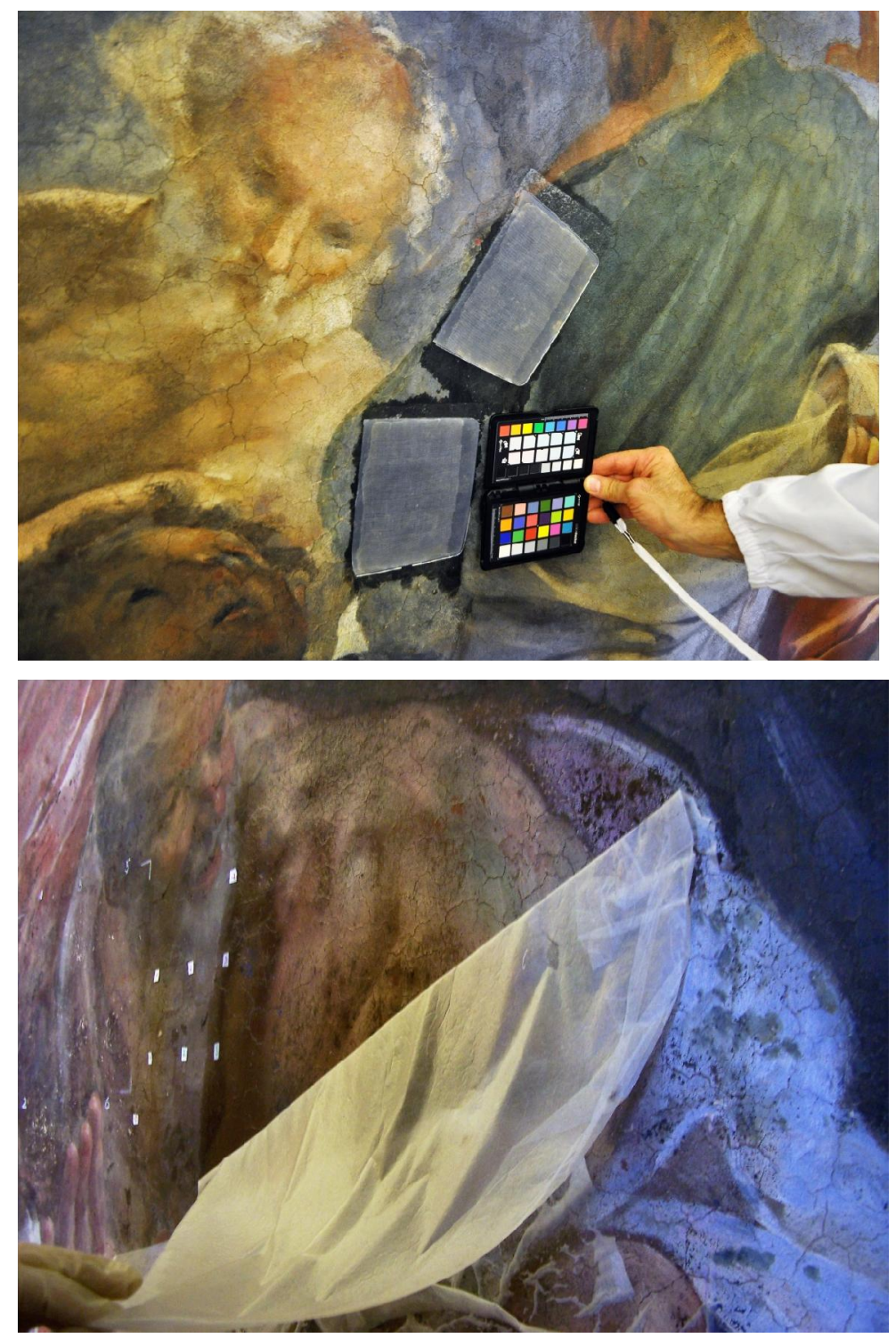

Figures 3a-3b Images of artwork tested at onsite cleaning, La Navicella wall painting, Vatican Museums, Rome. Detail of biocleaning by agargauze biogel activated with $P$. stutzeri.

\section{Results}

\section{Chemical and physical analyses before the biocleaning}

$\mathrm{Py} / \mathrm{GC}-\mathrm{MS}$ results confirmed the presence of fatty acids and protein residues on the La Navicella and Incarnato wall paintings. In particular, pyrolisis of the superficial layer of the sample from the Navicella, confirmed the presence of numerous materials: proteinaceous material with the presence of traces of hexadecanenitrile and octadecanenitrile, confirming the presence of egg; cholesterol and fatty acids, such as azelaic acid, myristic acid, palmitic acid and stearic acid, revealed the presence of a lipid component. In fact, in addition to the lipid component of the egg, other sources of lipid material have also been identified like long fatty acid chains and their isomers C15, C17 and C19, which are characteristic of animal-fat material, as shown by the extract ions m/z 299, 327, 355 in Figure 4. 
In FTIR spectra of the La Navicella samples, the absorbance bands around 1435, 874 and $713 \mathrm{~cm}^{-1}(\mathrm{C}=\mathrm{O}$ asymmetric stretching, out-of-plane bending, and in-plane bending vibrations, respectively) and around 1623 and $1315 \mathrm{~cm}^{-1}$ (CO stretching vibrations) showed the presence of calcite and calcium oxalate as whewellite $\mathrm{CaC}_{2} \mathrm{O}_{4} * \mathrm{H}_{2} \mathrm{O}$, respectively (Petrov and Šoptrajanov 1975; Derrick et al. 1999; Bugini et al. 2017; Rampazzi et al. 2018). The S-O asymmetric stretching signals at 1145, 1116 and bending mode at $669 \mathrm{~cm}^{-1}$ also revealed small amounts of gypsum, and the absorbance around $1385 \mathrm{~cm}^{-1}$ suggested an alkaline nitrate (Petrov and Šoptrajanov 1975; Derrick et al. 1999). Calcite derives from the carbonatic substrate unintentionally sampled, while calcium oxalate, gypsum and alkaline nitrate are neo-formation compounds from well-known decay phenomena of stone materials (Amoroso and Fassina 1983; Rampazzi 2019). Weak bands around 2915 and $2850 \mathrm{~cm}^{-1}$ were observed, probably due to $\mathrm{CH}$ stretching signals of traces of organic compounds, but definitive identification was not possible (Derrick et al. 1999). Silicate signals were present in the spectrum of sample LN1, which may be ascribed to unintentional substrate sampling. In sample LN2 peaks representing basic copper carbonate indicated the presence of the pigment azurite.

For the Incarnato samples, FTIR analyses of the external surface of the 4 samples (IN1a-IN4a) showed the specific calcite signals at 1433 (asymmetric C-O stretching band), 874 (out-of-plane bending vibration) and $713 \mathrm{~cm}^{-1}$ (inplane bending vibration) and those of silicates at around 1000-1100 $\mathrm{cm}^{-1}$ (Derrick et al. 1999; Rampazzi et al. 2011), both deriving from the unintentionally sampled substrate. The spectra also showed characteristic aliphatic carbon hydrogen stretches (methyl and methylene groups) at 2923 and $2852 \mathrm{~cm}^{-1}$ and an absorbance-signal band around 1700 and $1246 \mathrm{~cm}^{-1}$, which may be associated with carbonyl stretching and $\mathrm{N}-\mathrm{H}$ deformation/C-N stretching, respectively. The pattern of the bands suggests that the organic substance is a proteinaceous compound (Derrick et al. 1999).

\section{Biocleaning treatments of the selected areas}

The complete removal of organic compounds depended on the thickness of the layer and on the duration and type of application. Some areas were completely cleaned, while others still showed the presence of residues at the end of the biotreatment. The results of the onsite trials using agar-gauze biogel enriched with Pseudomonas stutzeri cells at different application times (12 hours for the Cupola at Pisa Cathedral; 60 and 150 minutes at the Vatican Museum) are shows in Table 3. An evaluation of the advantages of the biocleaning treatments is also reported: the performance of the agar-gauze biogel adopted in this study shows good adhesion on different surfaces, dehydration and detachment and it is easy to apply and to remove. Rare instances of leakages (colature) were observed during the adhesion on the vaulted/oblique internal wall-surfaces at the Cupola (Figures S2a-d).

As regards La Navicella wall-painting, two areas of the painting were tested; a small area of the artwork featuring the red cape of the lower left figure, was initially treated with P. stutzeri for approximately 150 minutes. Approximately $25 \mathrm{~cm}^{2}$ of agar gel was applied in triplicate over a layer of protective Japanese paper, both with bacteria and without, using water instead of the bacterial solution, as a control (see Materials and methods).

Once the results of the biocleaning had been verified, a larger area of about $1,000 \mathrm{~cm}^{2}$ (on the green cape of the upper right figure) was treated. In this case, we used agar-gauze biogel, which allowed better adhesion during the bioapplication on vertical walls. In fact, the conservators were able to adapt the agar-gauze biogel and to cut it according to the size and shape of the areas selected, for the presence of painted objects or figures. Additional treatments lasting 60 minutes were tested with control tests in parallel. 
Table 2 Onsite results of biocleaning treatments on vertical wall painting artwork Cristo che salva Pietro dalle acque - La Navicella and vaulted wall painting on the Cupola Incarnato at Pisa, affected by proteinaceous residues.

\begin{tabular}{|c|c|c|c|c|}
\hline Parameters & \multicolumn{2}{|c|}{ The Navicella wall painting (Vatican Museum) } & \multicolumn{2}{|l|}{ Incarnato - Internal wall inside the Cupola, Pisa } \\
\hline Treatments & $\begin{array}{l}\text { Control - agar gauze } \\
\text { (no bacteria) }\end{array}$ & $\begin{array}{l}\text { Agar gauze-biogel } \\
\text { activated bacteria }\end{array}$ & $\begin{array}{l}\text { Control - agar gauze } \\
\text { (no bacteria) }\end{array}$ & Agar gauze-biogel activated bacteria \\
\hline \multicolumn{5}{|l|}{ FTIR } \\
\hline Before & $\begin{array}{l}\text { Organic compounds } \\
(\approx 5 \% \mathrm{w} / \mathrm{w})\end{array}$ & $\begin{array}{l}\text { Organic compounds } \\
(\approx 5 \% \mathrm{w} / \mathrm{w})\end{array}$ & $\begin{array}{l}\text { Proteinaceous compounds }(\approx 11 \% \mathrm{w} / \mathrm{w}) \\
\text { Proteinaceous compounds }(\approx 11 \% \mathrm{w} / \mathrm{w})\end{array}$ & $\begin{array}{l}\text { Proteinaceous compounds }(\approx 11 \% \mathrm{w} / \mathrm{w}) \\
\text { Proteinaceous compounds } \approx \text { LOD }\end{array}$ \\
\hline After & Organic compounds $(\approx 5 \% \mathrm{w} / \mathrm{w})$ & $\begin{array}{l}\text { Organic compounds } \\
\approx \text { LOD }\end{array}$ & Organic substances (Abundance $\approx 350.000$ ) & Organic substances (Abundance $\approx 350.000$ ) \\
\hline $\begin{array}{l}\mathrm{Py} / \mathrm{GC}- \\
\mathrm{MS}\end{array}$ & $\begin{array}{l}\text { Organic substances (Abundance } \\
\approx 140.000 \text { ) }\end{array}$ & substances & Organic substances (Abundance $\approx 350.000$ ) & Organic substances (Abundance $\approx 20.000$ ) \\
\hline Before & $\begin{array}{l}\text { Organic substances (Abundance } \\
\approx 140.000 \text { ) }\end{array}$ & $\begin{array}{l}\text { (Abundance } \approx 140.000) \\
\text { Organic } \quad \text { substances }\end{array}$ & & \\
\hline After & & (Abundance $\approx 20.000$ ) & & \\
\hline
\end{tabular}

Legend - LOD, Limit of detection: FTIR $(\approx 0.5 \% \mathrm{w} / \mathrm{w})$; Py/GC-MS Limit of detection of the Ion Current Abundance of the extract ion $\mathrm{m} / \mathrm{z}$ $194 / 208$ and 222/236, characteristic for the markers of egg (Abundance $\approx 20.000$ ) (Colombini et al., 2003; Ranalli et al., 2005).

\section{Microbiological monitoring of the biorestoration process}

The microbiological monitoring performed immediately after the removal of the agar biogels at the Vatican Museum, and two months after the biotreatment on the Cupola at Pisa Cathedral, showed the absence, or very low presence, of viable cells (ranging from 0 to $8 \mathrm{CFU} / 100 \mathrm{~cm}^{2}$ ); the bacterial colonies detectable were not attributable to the bacterial strain used for the biocleaning. In fact, on the Cupola the bacterial colonies grown on the agarized plates were characterized by pigmentation (yellow and orange color) ascribable to outdoor environment. Similar results were found over time in the biotreated and untreated control areas by determining ATP contents, suggesting that the treated artworks do not show any significant changes in viable microbial counts. Temperature monitoring during the biocleaning indicated that the recorded temperature was stable at around $21 \pm 2.0^{\circ} \mathrm{C}$ at the Vatican Museum room. On the contrary, recorded temperatures during the biotreatment carried out inside the Cupola at Pisa Cathedral ranged from 17 to $24^{\circ} \mathrm{C}$ (with day / night variation); these environmental conditions, however, ensured favourable bacterial metabolic activity.

\section{Chemical and physical analyses after the biocleaning}

After the treatment, some micro-fragments of the painting films were taken, in the same homogeneous areas as the previously analyzed samples (Table 2, Figure 4), in order to determine the composition. The results confirmed the absence or very low amounts of organic materials, which, at least, could be below the limits of instrument sensitivity. The Py/GC-MS limit of detection of the Ion Current Abundance of the extract ion m/z 194/208 and 222/236, characteristic for the markers of egg was Abundance $<20.000$. The Py-GC/MS analysis in fact attested to the effectiveness of the cleaning in removing the proteinaceous material, as visible from the comparison of the extract ion pyrogram of the material collected before and after cleaning, of $\mathrm{m} / \mathrm{z}$ 194/208 and 222/236, which are characteristic of the markers for egg hexadecanenitrile and octadecanenitrile, respectively. (Table 3, Figure 5). In La Navicella FTIR spectra too the weak signals of organic compounds previously observed were no longer detected. With regards to the Incarnato, FTIR signals were quite similar to those observed before the biocleaning. Specific calcite and silicate signals were still present. The spectra also showed very weak signals at $2923,2852 \mathrm{~cm}-1$ and at around $1700 \mathrm{~cm}-1$, which are characteristic of aliphatic carbon hydrogen stretches (methyl and methylene 
groups) and carbonyl stretching, respectively. The absorbance pattern indicated the same proteinaceous compound determined in the painting film before the biocleaning, but at very low concentration. The limit of detection for FTIR was $0.5 \% \mathrm{w} / \mathrm{w}$. (Table 3).
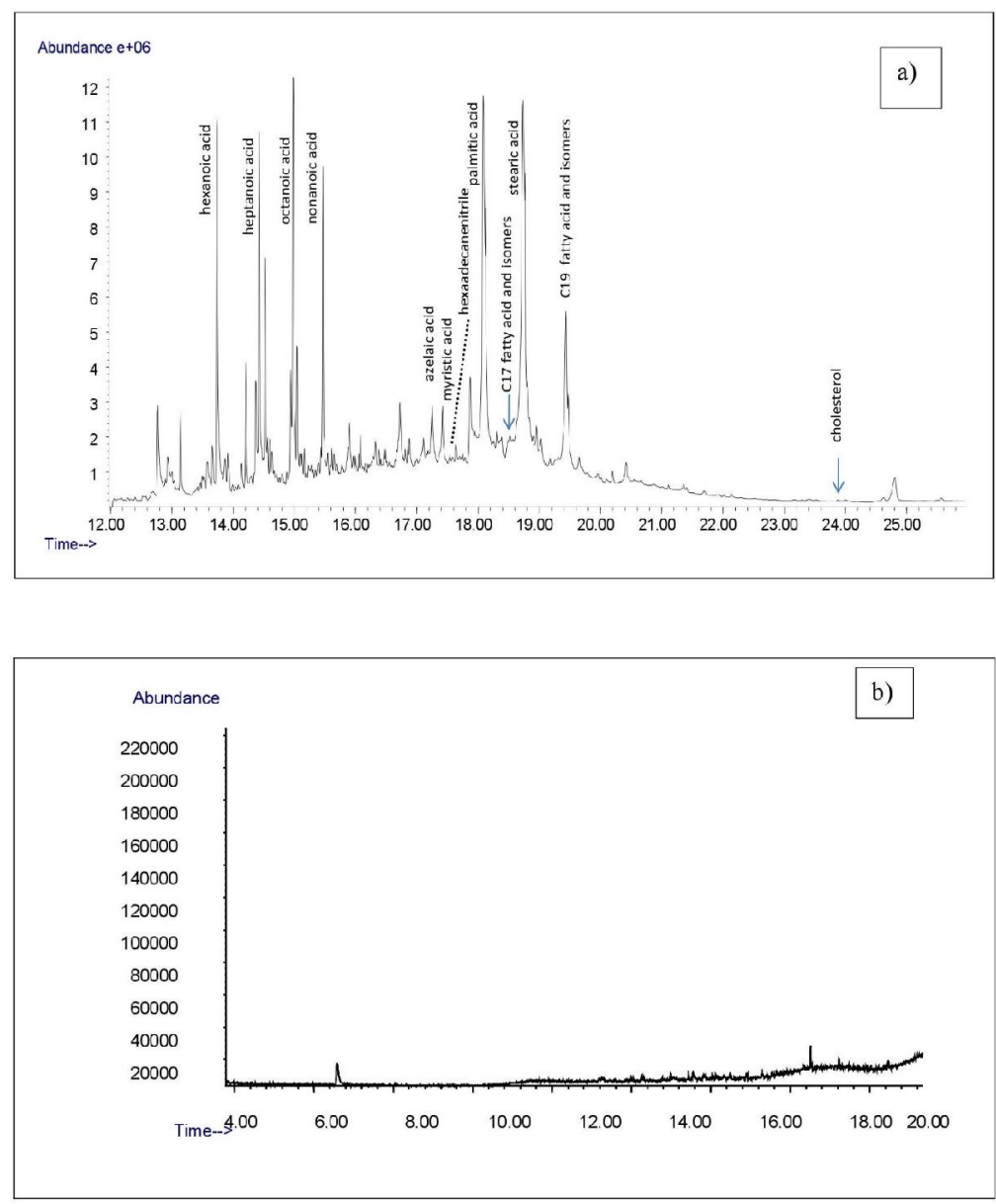

Figure 4 Pyrogram in extract ions m/z 299, 327, 355 of La Navicella sample, before biocleaning, characteristic of C15, C17 and C19 and their isomers.

\section{Discussion}

The success of the biotreatments performed using new biogel systems activated with viable bacterial cells shows that biocleaning is also highly-promising for wall-paintings and for the removal of various alterations. This is attributable to the great versatility of the bacteria and their wide range of enzymatic activities. Bacteria are known to produce not only constitutive, but also inducible enzymes that can attack and degrade different types of molecules. The synthesis of inducible enzymes only takes place in the presence of a substrate, creating a regulatory effect. Thus, the use of microorganisms is more effective than the use alone of a single enzyme that only attacks specific bonds. Moreover, constitutive and induced enzymes of viable cells of versatile bacteria like Pseudomonas strains are able to degrade a wide spectrum of organic compounds (Bosch-Roig et al. 2016). Several factors, including temperature, relative humidity, $\mathrm{pH}$, carbon and energy sources and inhibitors (metal ions, etc.) can influence metabolic activity. Thus, in order to confirm predicted metabolic efficiency, laboratory-scale experiments on artificial specimens are useful to optimize conditions before onsite application. 


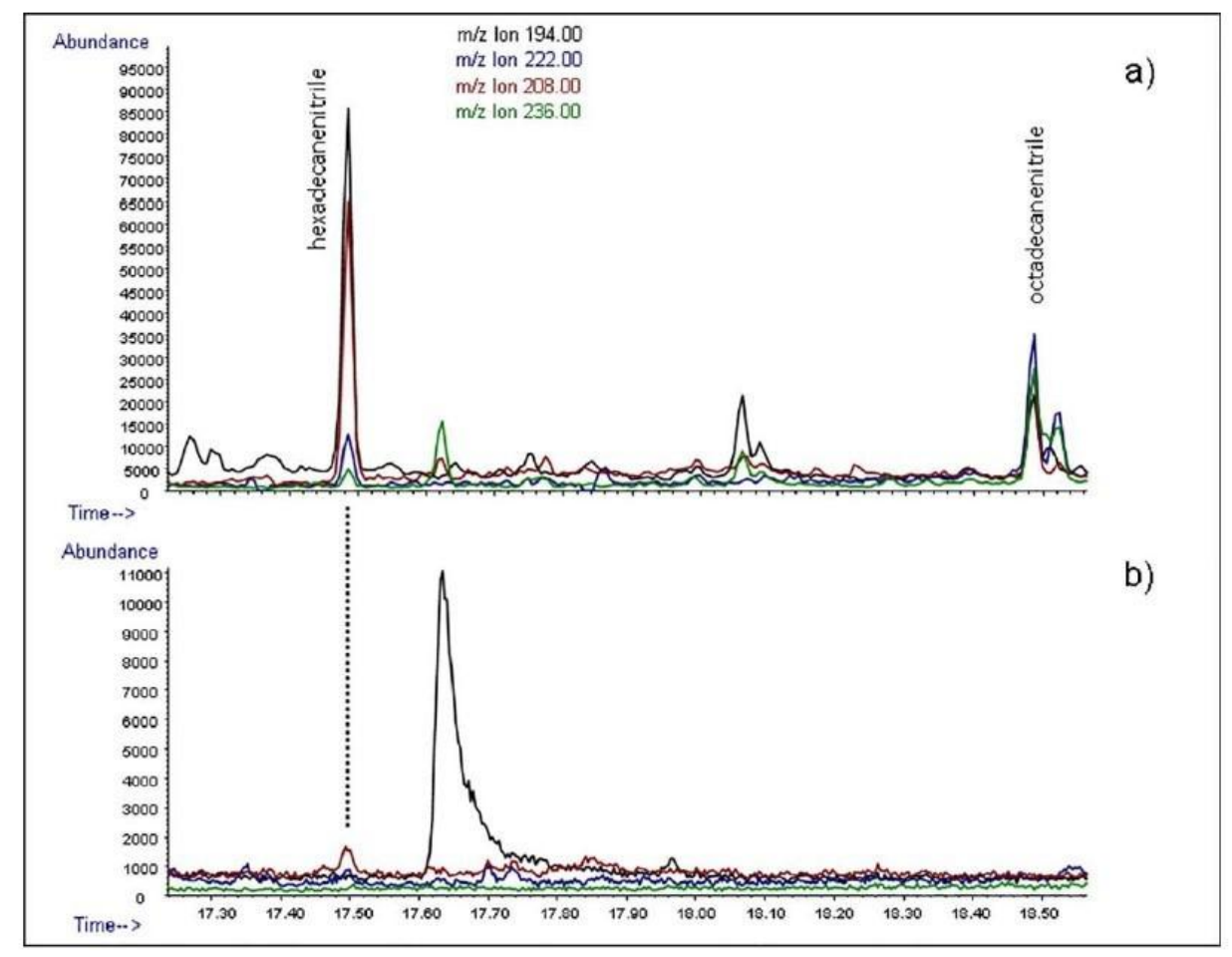

Figure 5 Pyrogram of the material collected before (a) and after cleaning (b) of the $\mathrm{m} / \mathrm{z}$ 194/208 and 222/236, characteristic of the markers for egg hexadecanenitrile and octadecanenitrile, respectively.

In the biorestoration of artworks, biocleaning requires the use of selected microorganisms on the altered surface. The success of the application depends on the type of alteration, the artwork material and its condition, the location of the areas undergoing treatment and the metabolic activity of the selected microflora (aerobic and/or anaerobic processes). In addition, the complete removal and the overall effectiveness of the biological process can be influenced by the duration of the treatment (Ranalli et al. 2005). The state of conservation of the artwork, which also depends on the original materials used, can be critical for many reasons; in this phase it is crucial to reduce to the minimum both the volume of water added to the material and the contact time on the artwork surface. While mechanical and chemical methods commonly used to clean and restore artwork surfaces are not always satisfactory (not efficient enough and/or too invasive), short and fast biocleaning processes based on the use of a selected strain of viable cells represent a promising method and a more versatile alternative.

When artwork undergoes a restoration process, generally an accurate cleaning phase is required at the end of the biocleaning process to carefully remove the bacterial cells used as biocleaning agents and to avoid undesired metabolic processes. Therefore, an adequate strategy for the future protection of artwork needs to include an accurate cleaning phase, because, if the microorganisms remain viable and active, they may cause material loss or damage, either directly, or as a consequence of their metabolic by-products (Bosch-Roig and Ranalli, 2014).

Possible damage due to prolonged bacterial treatment on artworks has been also demonstrated in previous studies by Ranalli et al. (2003a) and Ranalli et al. (2003b) and, therefore, it is very important to appropriately define the duration of the application. Rapid analyses are also fundamental for the monitoring of the biorestoration processes and therefore, fast analyses that measure the microbial activity like the monitoring of ATP content as viable biomass indicators, are of great benefit. 
In this study, $P$. stutzeri viable cells have been applied to clean two different wall-paintings using an advanced delivery system as agar-gauze biogel. The results reported in this paper show that this biotechnology, until now used for the recovery of frescoes, can be safely applied onsite to ancient paintings to bioclean vertical and vaulted wallsurfaces. Before proceeding the appropriate conditions, the ideal cell-carrier system (in this case the agar-gauze gel activated bacteria) and the appropriate duration of the application should be evaluated and optimized, in order to avoid potential inactivation of the biogel by de-hydration and possible detachment from the artwork surface.

This study also shows how this biotechnology can be useful and appropriate for the removal a mixture of mainly proteinaceous residues from wall-painting surfaces. The degradation of the residual compounds by bacterial activity (without the use of chemicals) leads to the natural release of carbon dioxide and water and the method can be therefore considered to be environmentally friendly (Bosch-Roig et al. 2016; Junier and Joseph, 2017). The performance of the agar-gauze biogel adopted in this study shows good adhesion on different surfaces, low risks of leakage, dehydration and detachment and it is easy to apply and to remove.

Recently the potential use of selected microorganisms to prevent biodeterioration of artworks has been also reported; the results suggested and indicated the ability of biocompound to counteract the growth of contaminating microorganisms potentially dangerous to paintings (Caselli et al. 2018).

Our results confirm the vast potential of biorestoration treatments as soft, but targeted, biotechnology aiming to recover altered artwork, being non-destructive and using non-pathogenic microorganisms and their natural metabolic activity. Therefore, biorestoration represents the development, under optimal conditions, of processes that spontaneously occur in natural environments and its application can be added to the ever-growing list of biotechnologies applied to the environment as promising and useful alternative methods in the conservation and preservation of our historic and artistic patrimony.

\section{Acknowledgements}

The work was supported partially by the Opera Primaziale Pisana (OPA) Pisa, Ing. G. Bentivoglio and partially by the VAL I + d APOSTD/2013/024 project by Generalitat Valenciana, Spain. The authors wish to thank the OPA Scientific Committee, under the direction of Prof. A. Paolucci, and the OPA Restoration Laboratories for the contribution of the conservation scientists.

The Authors are grateful to M. Ludmila Pustka, Ulderico Santamaria, and the restorer Giacomo Virdia of the Vatican Museums for their important help in supporting the application of the biocleaning tests; as well as to Claudia Sorlini for the suggestions and criticisms she contributed. The Authors would like to devote this manuscript to the memory of Donatella Zari. All authors reviewed the results and approved the final version of the manuscript. Finally, the Authors are grateful to S. Pool for editing the manuscript. The funders had no role in study design, data collection or interpretation, nor in the decision to submit the work for publication.

\section{Author contributions}

G.R., E.Z. coordinated the project and participated in the conception of the work, in the analysis of results, and in the writing the draft of the manuscript, A.A., M.P.C., L.R. contributed to design the experiment, analysis of the data, and contributed in manuscript preparation and its critical revision, P.B., G.L. contributed in the execution of part of the experimental work and in the acquisition of the data, C.C. contributed to the chemical analysis of samples, P.V., C.G., D.Z. coordinated and supervised all the conservation activities. All authors reviewed the results and approved the final version of the manuscript. 


\section{Conflict of interest}

The authors have no conflict of interest to declare.

\section{References}

Alfano, G., Lustrato, G., Belli, C., Zanardini, E., Cappitelli, F., Mello, E. et al. (2011). The bioremoval of nitrate and sulfate alterations on artistic stonework: The case-study of Matera Cathedral after six years from the treatment. Int Biodeterior Biodegrad 65:1004-1011.

Amoroso, G.G., Fassina, V. Stone Decay and Conservation. Atmospheric-pollution. Cleaning Consolidation and Protection, Elsevier, Amsterdam, 1983.

Andreotti, A., Bonaduce, I., Colombini, M.P., Modugno, F., Ribechini, E. (2009). The diagnosis of the yellowing of the marble hight-reliefs and the black decorations in the chapel of the tomb of Saint Anthony (Padua-Italy). $J$ Mass Spectrom 284:123-130.

Antonioli, P., Zapparoli, G., Abbruscato, P., Sorlini, C., Ranalli, G., Righetti, P.G. (2005). Art-loving bugs: The resurrection of Spinello Aretino from Pisa's cemetery. Proteomics 5: 2453-2459.

Barbabietola, N., Tasso, F., Grimaldi, M., Alisi, C., Chiavarini, S., Marconi, P. et al. (2012). Microbe-based technology for a novel approach to conservation and restoration. EAI Speciale II. Knowledge, Diagnostics and Preservation of Cultural Heritage, pp. 69-76.

Barras, F. (2018) Art and microbiology: encounters of the third type. Environ Microbiol Reports, doi:10.1111/17582229.12717

Bosch-Roig, P., Montes-Estellés, R.M., Regidor-Ros, J.L., Roig Picazo, P., Ranalli, G. (2012). New frontiers in the microbial bio-cleaning of artworks. Picturer Restorer 41: 37-41.

Bosch-Roig, P., Regidor-Ros, J.L., Soriano-Sancho, P., Montes-Estellés, R.M. (2013a). Biocleaning of animal glue on wall paintings by Pseudomonas stutzeri. Chem Today 31: 50-53.

Bosch-Roig, P., Regidor-Ros, J.L., Montes Estellés, R.M. (2013b). Biocleaning of nitrate alterations on wall paintings by Pseudomonas stutzeri. Int Biodeterior Biodegrad 84: 266-274. doi: 10.1016/j.ibiod.2012.09.009

Bosch-Roig, P., Lustrato, G., Zanardini, E., Ranalli, G. (2014). Biocleaning of Cultural Heritage stone surfaces and frescoes: which delivery system can be the most appropriate? Ann Microbiol 65: 3, 1227-1241.

Bosch-Roig, P. and Ranalli, G. (2014). The safety of biocleaning technologies for cultural heritage. Front Microbiol 5:155. doi:10.3389/fmicb.2014.00155

Bosch-Roig, P., Decorosi, F., Giovannetti, L., Ranalli, G., Viti, C. (2016) Connecting phenome to genome in Pseudomonas stutzeri 5190: an artwork biocleaning bacterium. Res Microbiol 167: 757-765. https://doi.org/10.1016/j.resmic.2016.09.003.

Bosch-Roig, P. and Ranalli, G. (2018). Biocleaning of cultural heritage treasures. In: Biodeterioration and Preservation in Art, Archeology and Architecture, ed. Mitchell, R. and Clifford, J. pp. 169-183, London, Archetype Publications.

Bugini, R., Corti, C., Folli, L., Rampazzi, L. (2017). Unveiling the use of creta in Roman plasters: analysis of clay wall paintings from Brixia (Italy). Archaeom 59: 84-95.

Cappitelli, F., Zanardini, E., Ranalli, G., Mello, E., Daffonchio, D., Sorlini, C. (2006). Improved methodology for bioremoval of black crusts on historical stone artworks by use of sulfate-reducing bacteria. Appl Environ Microbiol 72: 3733-3737. 
Cappitelli, F., Toniolo, L., Sansonetti, A., Gulotta, D., Ranalli, G., Zanardini, E., Sorlini, C. (2007). Advantages of using microbial technology over traditional chemical technology in the removal of black crusts from stone surfaces of historical monuments. Appl Environ Microbiol 73: 5671-5675.

Caselli E., Pancaldi, S., Baldisserotto, C., Petrucci, F., Impallaria, A., Volpe, et al. (2018) Characterization of biodegradation in a 17 th century easel painting and potential for a biological approach. PLOS, December 5, doi.org/10.1371/journal.pone.0207630

Cremonesi, P. (1999). L’uso degli enzimi nella pulitura delle opere policrome. In: I Talenti ed. Cremonesi, P. pp. 511. Padova: Il Prato.

Colombini, M.P., Modugno, F. Giacomelli, A. (1999). Two procedures for suppressing interference from inorganic pigments in analysis by gas chromatography-mass spectrometry of proteinaceous binders in painting. J Chrom Acta 846: 101-111.

Colombini, M.P., Bonaduce, I., Gautier, G. (2003). Molecular pattern recognition of fresh and aged shellac. Chromatographia 58:1-8.

Corti, C., Rampazzi, L., Visonà, P. (2016). Hellenistic Mortar and Plaster from Contrada Mella near Oppido Mamertina (Calabria, Italy). Int J Conserv Scie 7: 57-70.

De Belie, N., De Graef, B., De Muynck, W., Dick, J., De Windt, W., Verstraete, W. (2005). Biocatalytic processes on concrete: bacterial cleaning and repair. Proceedings of the 10th International Conference on Durability of Building Materials and Components, Lyon, pp. 95-103.

De Graef, B., De Windt, W., Dick, J., Verstraete, W., De Belie, N. (2005). Cleaning of concrete fouled by lichens with the aid of Thiobacilli. Mater Struct 38: 875-882. doi:10.1007/BF02482254

Derrick, M.R., Stulik, D., Landry, J.M. Infrared Spectroscopy in Conservation Science, Getty Conservation Institute 1999.

Doehne, E. and Price, C.A. (2010). Stone Conservation. An overview of Current Research. The Getty Conservation Institute, Los Angeles, p. 175.

Gauri, K.L., Chowdhury, A.N., Kulshreshtha, N.P., Punuru, A.R. (1989). The sulfation of marble and the treatment of gypsum crusts. Stud Conserv 34: 201-206.

Gioventù, E., Lorenzi, P.F., Villa, F., Sorlini, C., Rizzi, M., Cagnini, et al. (2011). Comparing the bioremoval of black crusts on colored artistic lithotypes of the Cathedral of Florence with chemical and laser treatment. Int Biodeterior Biodegrad 65: 832-839.

Junier, P. and Joseph, E. (2017) Microbial biotechnology approaches to mitigating the deterioration of construction and heritage materials. Microb Biotech 10: 1145-1148 doi:10.1111/1751-7915.12795.

Lluveras, A., Bonaduce, I., Andreotti, A., Colombini, M. P. (2010). A GC/MS analytical procedure for the characterization of glycerolipids, natural waxes, terpenoid resins, proteinaceous and polysaccharide materials in the same paint micro sample avoiding interferences from inorganic media. Anal Chem 81:376-386.

Lustrato, G., Alfano, G., Andreotti, A., Colombini, M.P., Ranalli, G. (2012). Fast biocleaning of mediaeval frescoes using viable bacterial cells. Int Biodeterior Biodegrad 69: 51-61.

May, E., Webster, A.M., Inkpen, R., Zamarreño, D., Kuever, J., Rudolph, C., Warscheid, T., Sorlini. C., Cappitelli, F., Zanardini, E., Ranalli, G., Krage, L., Vgenopoulos, A., Katsinis, D., Mello, E., Malagodi, M. (2008). The BIOBRUSH project for bioremediation of Heritage stone. In: May, E., Jones, M., Mitchell, J. (eds.) Heritage Microbiology and Science. Microbes, Monuments and maritime materials. RSC Publishing, Cambridge, pp. 7693. 
Mazzoni, M., Tasso, F., Alisi, C., Cecchini, A., Marconi, A., Sprocati, A.R. (2014). Laponite micro-packs for the selective cleaning of multiple coherent deposits on wall paintings: The case study of Casina Farnese on the Palatine Hill (Rome-Italy). Int Biodeterior Biodegrad 94:1-11. doi:10.1016/j.ibiod.2014.06.004

Orsini, S., Parlanti, F., and Bonaduce, I. (2017). Analyical pyrolysis of proteins in samples from artistic and archaeological objects. J Anal Appl Pyrolysis, 124:643-657.

Polo, A., Cappitelli, F., Brusetti, L., Principi, P., Villa, F., Giacomucci, L., et al. (2010). Feasibility of removing surface deposits on stone using biological and chemical remediation methods. Environ Microbiol 60:1-14.

Petrov, I. and Šoptrajanov, B. (1975). Infrared spectrum of whewellite, Spectrochim Acta Part A. Mol Spectrosc 31, 309-316.

Rampazzi, L., Giussani, B., Rizzo, B., Corti, C., Pozzi, A., Dossi, C. (2011). Monuments as sampling surfaces of recent traffic pollution. Environ Sci Pollut Res 18: 184-191.

Rampazzi, L., Rizzo, B., Colombo, C., Conti, C., Realini, M., Bartolucci et al. (2012). The stucco technique of the Magistri Comacini: the case study of St. Maria dei Ghirli in Campione d'Italia (Como, Italy). Archaeom 54: 926939.

Rampazzi, L., Colombini, M.P., Conti, C., Corti, C., Lluveras-Tenorio, A., Sansonetti, A. et al. (2016). Technology of Medieval mortars: an investigation into the use of organic additives. Archaeom 58: 115-130.

Rampazzi, L., Andreotti, A., Bressan, M., Colombini, M.P., Corti, C., Cuzman, O. et al. (2018). An interdisciplinary approach to a knowledge-based restoration: the dark alteration on the Matera Cathedral (Italy). Appl Sur Sci 458: 529-539.

Rampazzi, L. (2019). Calcium oxalate films on works of art: a review'. J Cult Herit in press.

Ranalli, G., Belli, C., Baracchini, C., Caponi, G., Pacini, P., Zanardini, E., Sorlini, C. (2003a). Deterioration and bioremediation of frescoes: A case study. In: Saiz-Jimenez, C. (ed.) Molecular Biology and Cultural Heritage. Balkema Publishers, Netherlands, pp. 243-246.

Ranalli, G., Zanardini, E., Pasini, P., Roda, A. (2003b). Rapid biodeteriogen and biocide diagnosis on artwork: a bioluminescent low-light imaging technique. Ann Microbiol 53: 1-13.

Ranalli, G., Alfano, G., Belli, C., Lustrato, G., Colombini, M.P., Bonaduce, I. et al. (2005). Biotechnology applied to cultural heritage: biorestoration of frescoes using viable bacterial cells and enzymes. J Appl Microbiol 98: 7383.

Ranalli, G., Zanardini, E., Sorlini, C. (2009). Biodeterioration including Cultural Heritage. In: Schaechter M (ed.) Encyclopedia of Microbiology, $3^{\text {rd }}$ ed. Elsevier, Oxford, pp. 191-205.

Ranalli, G., Zanardini, R., Andreotti, A., Colombini, M.C., Corti, C., Bosch-Roig, P. et al. (2018). Hi-tech restoration by two steps biocleaning process of Triumph of Death fresco at the Camposanto Monumental Cemetery (Pisa, Italy). J Appl Microbiol doi: 10.1111/jam.13913.

Saiz-Jimenez, C. (1995). Deposition of anthropogenic compounds on monuments and their effect on airborne microorganisms. Aerobiol 11:161-175.

Saiz-Jimenez, C. (2004). Air Pollution and Cultural Heritage. Proceedings of the International Workshop on Air Pollution and Cultural Heritage, Seville, Spain. Leiden and New York: Balkema.

Troiano, F., Gulotta, D., Balloi, A., Polo, A., Toniolo, L., Lombardi, E. et al. (2013). Successful combination of chemical and biological treatments for the cleaning of stone artworks. Int Biodeterior Biodegrad 85:294304.

Wolbers, R. (2000) In Archetype. Cleaning painted surface: Aqueous Methods, London. 